\title{
PENGARUH KUALITAS JASA TERHADAP KEPUASAN NASABAH PADA BANK UMUM SYARIAH DI SURAKARTA
}

\author{
Ulul Azmi Mustofa ${ }^{1}$ dan Yudi Siyamto ${ }^{2}$ \\ STIE AAS Surakarta \\ ${ }^{I}$ Email: ulul.azmi@yahoo.com \\ ${ }^{2}$ Email:yudi.siyamto@yahoo.com
}

\begin{abstract}
The purpose of this study was to determine whether there is influence of service quality on customer satisfaction Islamic banks, so as to identify which dimension of service quality that is dominant in influencing customer satisfaction.

Variables used consists of dimensional compliance, assurance, reliability, tangible, empathy and responsiveness known CARTER name. This research was conducted in the region with a population Surakarta Islamic commercial bank customers are categorized as foreign banks with a sample of 90 respondents, as well as the sampling process is done by accidental sampling.

The results showed that partially dimensional compliance, reliability, tangibility, empathy, responsiveness individual has an influence on customer satisfaction Islamic commercial bank. As for the variables assurance there are no significant effects. In this case the use CARTER dimension is good enough since it simultaneously has the effect on customer satisfaction.
\end{abstract}

Keywords: Service Quality, Customer Satisfaction, CARTER

\section{PENDAHULUAN}

Seiring dengan semakin berkembangnya bank di Indonesia baik bank konvensional maupun bank syariah membawa dampak pada persaingan bebas dalam meningkatkan daya saing. Berbagai jenis fasilitas yang ditawarkan untuk memperoleh hasil yang diharapkan oleh setiap perusahaan. Perdagangan bebas yang terjadi saat ini mengakibatkan setiap perusahaan harus menghadapi persaingan yang ketat. Meningkatnya intensitas persaingan dan jumlah pesaing, menuntut perusahaan untuk selalu memperhatikan kebutuhan dan keinginan pelanggan serta berusaha memenuhi harapan pelanggan dengan cara memberikan pelayanan yang lebih memuaskan dari pada yang dilakukan oleh pesaing.

Pertumbuhan bank umum yang berada di Surakarta pada januari 2013 mencapai Rp. 42,84 triliun atau tumbuh 22,61 persen. Pertumbuhan total aset bank umum, terutama dipengaruhi oleh meningkatnya simpanan masyarakat yang mencapai Rp. 32,97 triliun atau tumbuh 13,82 persen (http://economy. okezone.com).

Jika ditinjau dari segi aset, komposisi perbankan syariah di Surakarta hingga Agustus 2014 sebanyak 7,39 persen, sedangkan prosentase aset perbankan syariah secara nasional baru $4 \%$. Kepala Otoritas Jasa Keuangan (OJK) Solo 
Mulyadi menyatakan bahwa masih melambatnya pertumbuhan perbankan syariah di wilayah Surakarta itu dikarenakan prosentase asetnya masih cukup kecil yaitu sebesar $7,39 \%$ dari total aset perbankan sebanyak Rp 60,1 triliun, sedangkan perbankan konvensional mendominasi 90\%. Meski secara nasional lebih tinggi, namun prosentase $7,39 \%$ itu memang masih sangat kecil dari total aset perbankan di Surakarta sebanyak Rp 60,1 triliun, karena sebanyak 90\%, masih didominasi perbankan konvensional (http://rri.co.id).

Mengingat besarnya pengaruh kepuasan nasabah terhadap kinerja bank maka diperlukan beberapa upaya untuk menyelesaikan persoalan tersebut, Sylvana, Andi (2006) menyatakan bahwa upaya peningkatan kualitas merupakan suatu solusi untuk mencapai keunggulan kompetitif. Peningkatan kualitas merupakan salah satu strategi bisnis yang digunakan untuk meningkatkan kepuasan pelanggan. Kepuasan pelanggan akan tercapai apabila kualitas produk atau jasa dapat terpenuhi sesuai kebutuhannya.

$$
\text { Hasan (2010) menyatakan }
$$

Kepuasan pelanggan bergantung kepada persepsi pelanggan, jika yang dipersepsikan oleh pelanggan berkualitas, maka kualitas itu dapat memberikan dorongan kepada pelanggan untuk menjalin ikatan hubungan yang kuat dengan perusahaan dalam jangka panjang, ikatan seperti ini memungkinkan perusahaan untuk secara terus-menerus dapat memahami dengan seksama harapan pelanggan serta kebutuhan mereka.

Kualitas pelayanan di bank syariah, banyak kritik dari masyarakat terutama mengenai penerapan sistem bagi hasil yang diterapkannya. Beberapa diantara mereka meragukan kesesuaian bank syariah yang sesuai dengan syariat Islam. Selain itu, beberapa keluhan pelayanan di bagian front office yang terkesan kurang profesional juga banyak dilontarkan masyarakat. Hal tersebut tentu saja harus segera diselesaikan untuk menjaga loyalitas nasabah yang mengutamakan prinsip syariah sebagai motivator untuk menggunakan bank syariah. Astuti et al, (2009) menyatakan bahwa Upaya yang memungkinkan untuk dilakukan adalah dengan memperbaiki dan meningkatkan pelayanan bank syariah yang di dalamnya juga melibatkan kesesuaian produk dengan prinsip syariah yang menjadi pembeda bank syariah dengan bank konvensional.

Salah satu strategi dalam menangkap peluang maupun memperluas jangkauan pasar dapat dilakukan melalui pemasaran. Ada beberapa strategi pemasaran yang dapat diterapkan oleh perusahaan jasa seperti perbankan syariah yaitu salah satunya dengan peningkatan kualitas pelayanan yang ditekankan pada pemenuhan keinginan pelanggan/nasabah. Untuk meningkatkan kepercayaan dan kepuasan nasabah adalah dengan meningkatkan kualitas pelayanan jasa perbankan. Salah satu model pengukuran kualitas jasa tersebut adalah dengan menggunakan model CARTER (compliance fully with Islamic law and principles, assurance, reliability, tangible, empathy dan responsiveness) yaitu pengukuran kualitas jasa berdasarkan prinsip syariah yang dikembangkan Othman dan Lynn Owen pada tahun 2001.

Upaya peningkatan kualitas pelayanan Bank Umum Syariah bersifat inovatif dan berorientasi pada kepuasan nasabah. Namun masih muncul pertanyaan, apakah hal tersebut telah benar-benar dapat memberikan kepuasan bagi nasabah Bank Syariah bila dilihat dari enam dimensi pelayanan yaitu compliance fully with Islamic law and principles (kemampuan untuk menjalankan sesuai dengan hukum Islam dan beroperasi di bawah prinsipprinsip Islam) tangibles (bukti langsung), reliability (kehandalan), responsiveness 
(daya tanggap), assurance (jaminan) dan empathy (empati). Maka dari itu perlu mengidentifikasi lebih jauh apakah pelayanan yang selama ini diberikan telah sesuai dengan harapan nasabah. Hal ini merupakan bukti dari bentuk perhatian Bank Umum Syariah terhadap kepuasan nasabahnya.

Berdasarkan hasil dari berbagai penelitian tersebut, tulisan ini bertujuan untuk menganalisis pengaruh kinerja kualitas jasa bank syariah yang ada dalam dimensi-dimensi CARTER terhadap kepuasan nasabah Bank Umum Syariah. Selain itu juga untuk mengetahui dan menganalisis dimensi kualitas jasa manakah yang dominan berpengaruh terhadap kepuasan nasabah.

\section{Kualitas Jasa}

Definisi-definisi kualitas adalah merupakan usaha perusahaan untuk menunjukkan bahwa setiap orang memerlukan definisi operasional mengenai kualitas. Definisi operasional merupakan deskripsi dalam ukuran-ukuran yang dikuantifikasikan mengenai apa yang diukur dan langkah-langkah yang perlu dilakukan untuk mengukurnya secara konsisten. Tujuan pengukuran ini adalah untuk menentukan kinerja aktual proses tersebut (Tjiptono, 2000 : 12-13).

Kotler (1994) mendefinisikan kualitas atau mutu dengan kecocokan penggunaan, kesesuaian pada kebutuhan, bebas dari penyimpangan dan seterusnya. Menurut American Society for Quality Control, kualitas adalah keseluruhan ciri atau sifat barang dan jasa yang berpengaruh pada kemampuannya memenuhi kebutuhan yang dinyatakan maupun yang tersirat. Parasuraman, Zeithaml, dan Berry dalam Kotler (1997) mengemukakan lima penentu kualitas jasa : keandalan (reliability), daya tanggap (responsiveness), kepastian (assurance), empati (emphaty) berwujud (tangibles).
Sedangkan item yang dikemukakan berjumlah 22 .

Abdul Qawi Othman dan Lynn Owen (2001) mengemukakan pentingnya bank Islam untuk mengadopsi kualitas jasa. Dari hasil penelitiannya ia mengusulkan penggunaan model baru dalam mengukur kualitas jasa bank Syariah yang disebut CARTER (Compliance, Assurance, Reliability, Tangibles, Emphaty, dan Responsiveness). Indikatornya terdiri atas 34 item, yaitu :

a. Compliance fully with Islamic law and principles, adalah kemampuan suatu perusahaan dalam melakukan operasional berdasarkan prinsipprinsip syariah, seperti prinsip tauhid, prinsip keseimbangan, rinsip kehendak bebas, dan prinsip pertanggungjawaban

b. Assurance, adalah jaminan keahlian yang dimiliki oleh para karyawannya, perusahaan menjamin bahwa mereka adalah tenaga-tenaga yang ahli dibidangnya, mendapatkan pendidikan dan latihan yang tepat, berpengalaman, memiliki dedikasi yang baik, dan dapat memberi-kan hasil pelayanan dengan segera dan akurat bebas dari kesalahan, bebas dari dari kecelakaan, dan menjamin rasa aman bebas dari resiko.

c. Reliability, adalah kemampuan memberikan pelayanan yang dijanjikan dengan segera, akurat dan memuaskan.

d. Tangibles, adalah berupa prasarana berwujud yang digunakan oleh perusahaan yang dapat dilihat dan dirasakan oleh para pelanggannya, misalnya fasilitas fisik berupa gedung, interior, perlengkapan dan peralatan yang digunakan untuk melayani pelanggan, sarana komunikasi dan prasarana pendukung lainnya.16 
e. Empathy, adalah kemudahan untuk melakukan hubungan secara pribadi, kekeluargaan dalam batasbatas menjunjung etika profesi. Seperti komunikasi yang baik, perhatian pribadi, mengenal nama dengan baik, memahami kebutuhan pelanggan, mau mengerti dan mendengarkan masalah-masalah yang dihadapi pelanggan.

f. Responsiveness (daya tanggap), adalah respon karyawan dalam membantu pelanggan dan memberi-kan pelayanan yang cepat dan tanggap, yang meliputi kesigapan karyawan dalam melayani pelanggan, kecepatan karyawan dalam menangani transaksi, dan penanganan atas keluhan pelanggan.18 Misalnya kesediaan untuk; segera memproses permohonan, melakukan pendaftaran, menganalisa, mendengarkan keluhan, menerima saran untuk melakukan perbaikan dan sebagainya.

\section{Kepuasan Nasabah}

Kepuasan atau ketidakpuasan adalah perasaan senang atau kecewa seseorang yang berasal dari perbandingan antara kesannya terhadap kinerja produk riil atau aktual dengan kinerja produk yang diharapkan (Sangadi dan Sopiah, 2013:180). Kotler (2006) dalam Wijaya (2011), mendefinisikan kepuasan pelanggan adalah tingkat perasaan seseorang setelah membandingkan kinerja (hasil) yang ia rasakan dibandingkan dengan harapannya. Pendapat lain yaitu Robledo (2001) dalam Astuti (2009) menyatakan bahwa kepuasan pelanggan didefinisikan sebagai selisih $(g a b)$ antara persepsi dan harapan konsumen, sedangkan kepuasan nasabah adalah perasaan pelanggan saat menerima dan setelah merasakan pelayanan bank
(Dharmayanti, 2006). Sehingga kriteria kepuasan yang ditinjau dari pendapat Robledo (2001) dalam Astuti (2009), menyatakan bahwa konsumen atau nasabah akan memiliki persepsi positif apabila penyedia jasa memenuhi atau melebihi apa yang diharapkan konsumen.

Dari beberapa definisi diatas terdapat kesamaan, yaitu menyangkut komponen kepuasan konsumen (harapan atau kinerja hasil yang dirasakan). Persepsi pelanggan terhadap kepuasan merupakan penilaian subjektif atas hasil yang diperolehnya. Secara konseptual, kepuasan pelanggan dapat digambarkan pada bagan dibawah ini (Wijaya, 2011:153):

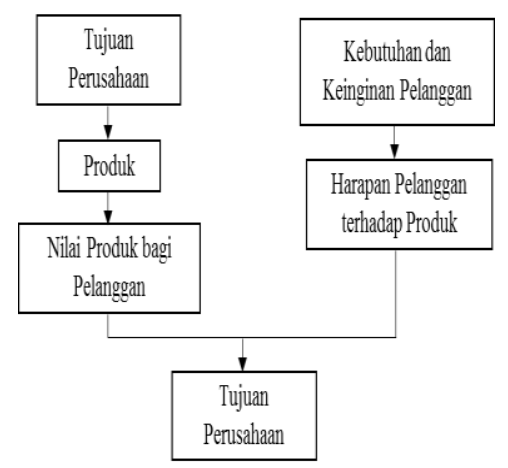

Sumber: Tjiptono (1997) dalam Toni Wijaya 2011

\section{Kerangka Berfikir}

Penelitian ini ingin mengetahui kinerja kualitas jasa yang dirasakan nasabah Bank Muamalat Indonesia Cabang Semarang dan pengaruhnya terhadap kepuasan nasabah. Kualitas jasa disini mempunyai enam dimensi,yaitu : Compliance, Assurance, Reliability, Tangibles, Empahty dan Responsivenes. Kemudian dari enam dimensi ini ingin diketahui pengaruhnya terhadap kepuasan nasabah. 


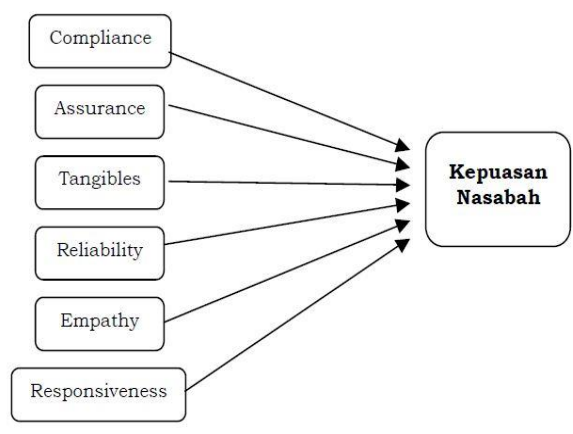

\section{Hipotesis}

Untuk menguji hipotesis penelitian ini, variabel dijelaskan dalam definisi konseptual dan operasional. Definisi konseptual dan perasional dari masingmasing variable ditampilkan dalam dimensi-dimensi sebagai berikut (Othman dan Owen, 2001).

$\mathrm{X} 1$ Compliance (kepatuhan yang berarti kemampuan untuk tunduk kepada hukum Islam dan beroperasi sesuai prinsip-prinsip perbankan dan ekonomi Islam.

X2 Assurance (jaminan) adalah pengetahuan dan kesantunan pegawai dan kemampuan mereka untuk menyampaikan kebenaran dan kerahasiaan. Hal ini juga meliputi komunikasi verbal dan tertulis antara pegawai bank dan nasabah.

X3 Reliability (kehandalan) adalah kemampuan untuk menyediakan layanan yang dijanjikan, konsisten dan akurat.

X4 Tangible (kenyataan) yang berarti tampilan dari fasilitas secara fisik peralatan, personel dan materi komunikasi.

X5 Emphaty (empati) adalah perhatian secara individu dimana bank-bank Islam menyediakannya untuk para konsumen.

X6 Responsiveness (ketanggapan) adalah kerelaan untuk membantu konsumen dan menyediakan layanan yang diminta.

\section{METODE PENELITIAN}

Penelitian ini merupakan jenis penelitian metode kuantitatif. Metode kuantitatif adalah analisis yang mempergunakan alat analisis yang bersifat kuantitatif, artinya alat analisis yang menggunakan model-model, kemudian hasilnya disajikan dalam bentuk angkaangka model statistik dan ekonometrik dan dijelaskan dan diintrepesentasikan dalam suatu uraian. (Hasan, 2002 : 98).

\section{Metode Pengumpulan Data}

Penelitian dan pengumpulan data dilakukan di daerah Surakarta tahun 2015. Objek yang digunakan dalam penelitian ini adalah nasabah yang mempunyai rekening di Bank Umum Syariah melalui penyebaran kuesioner dengan cara accidental sampling.

\section{Metode Analisis Data}

Teknik analisis data yang digunakan pada penelitian ini adalah dengan penggunaan alat regresi linier berganda. Uji validitas dan reliabilitas kuesioner diuji dengan menggunakan Korelasi Pearson dan Cronbach's alpha. Untuk memilih sampel digunakan metode accidental Sampling. Data sampel diperoleh sebanyak 90 responden dari beberapa cabang Bank Umum Syariah di Surakarta.

Berdasarkan identifikasi variabel di atas, persamaan regresi untuk menduga besar pengaruh masing-masing variabel bebas (X1, X2, X3, X4, X5 dan X6) terhadap kepuasan nasabah $(\mathrm{Y})$ disusun sebagai berikut:

$Y=\dot{\alpha}+\beta 1 X 1 i+\beta 2 X 2 i+\beta 3 X 3 i+\beta 4 X 4 i+$ $\beta 5 \mathrm{X} 5 \mathrm{i}+\beta 6 \mathrm{X} 6 \mathrm{i}+\mathrm{e}$

Di mana:

$\alpha:$ Konstanta

$\beta$ : Koefisien regresi

e : Faktor erorr 
Uji model regresi dilakukan sebelum analisis besaran penduga variable bebas dilakukan, yang meliputi uji normalitas, multikolinearitas, dan autokorelasi. Hasil dugaan persamaan regresi dianalisis dengan menggunakan beberapa uji statistik, yaitu:Koefisien Determinasi ( $\left.\mathrm{R}^{2}\right)$, Uji F (Ketepatan model), Uji t (Uji Parsial).

\section{HASIL DAN PEMBAHASAN}

Hasil uji reliabel instrumen pada masing-masing variabel menunjukkan bahwa instrumen telah reliabel, dengan nilai rata-rata (means) adalah compliance (0,683), assurance (0.644), reliability (0.604), tangible (0.778), emphaty (0.666), responsiveness $(0,621)$ dan kepuasan nasabah $(0,828)$ diamana nilai yang dihasilkan melebihi 0,6 , sehingga berdasarkan hasil pengujian tersebut dapat diketahui bahwa semua item pertanyaan yang telah diberikan kepada nasabah bank dapat dikatakan reliabel.

Sementara untuk pengujian validitas menunjukkan hasil kuesioner berjumlah 27 item dan berjumlah 7 variabel diperoleh hasil bahwa nilai $\mathrm{r}_{\text {-hitung }}$ kesemuannya yang dihasilkan melebihi $\mathrm{r}$ tabel sebesar 0,207, oleh karena itu dapat dikatakan seluruh item pernyataan valid, sehingga tidak ada item yang ditolak atau hilang dalam pengujian ini.

Uji normalitas digunakan untuk mengetahui apakah distribusi populasi data mengikuti distribusi normal atau tidak. Adapun hasil dari penelitian ini adalah : syariah

Hasil uji normalitas bank umum

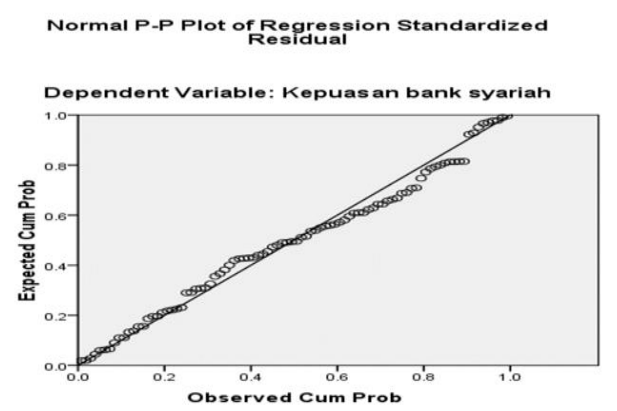

Sumber: data diolah, 2015

Gambar diatas menunjukkan adanya hubungan linier antara variabel compliance, assurance, reliability, tangibility, empathy, dan responsiveness karena sebaran data mengikuti garis lurus dari kiri bawah ke arah kanan atas, sehingga dapat disimpulkan dari kriteria pengujian, data tersebut dapat dikatakan berdistribusi normal.

Sementara uji multikolinieritas dapat dilihat dari nilai VIF, dimana nilai yang dihasilkan adalah kurang dari 10 dan nilai Tolerance tidak ada yang kurang dari 0,1 , sehingga model dapat dikatakan terbebas dari multikolinearitas. Jadi dapat disimpulkan variabel compliance, assurance, reliability, tangibility, empathy, dan responsiveness, dapat dikatakan tidak terjadi multikolinearitas pada model regresi.

Sedangkan jika dilihat dari pengujian autokorelasi menunjukkan bahwa nilai yang dihasilkan oleh Durbin Watson yaitu sebesar 1.963 dan nilai dl pada tabel DW sebesar 1.5181 serta nilai du sebesar 1.8014 dengan $\mathrm{k}$ (jumlah variabel bebas) adalah 6, maka berdasarkan kriteria pengujian yang telah dilakukan nilai DW berada pada du $<\mathrm{d}<4$ $-\mathrm{du}=1.8014<1.963<2.037$ sehingga dapat dikatakan model regresi tersebut terbebas dari autokorelasi positif maupun negatif. Pengujian lain dapat diketahui dari kriteria jika $1<\mathrm{DW}<3$, dengan nilai $1<$ $1.963<3$, maka kriteria tersebut dapat dikatakan tidak terjadi auokorelasi. Jadi dari hasil pengujian tersebut dapat 
disimpulkan bahwa model regresi varibel compliance, assurance, reliability, tangibility, empathy, dan responsiveness, dapat dikatakan tidak terjadi atau terbebas dari autokorelasi.

Hasil pengujian koefesien determinasi yang dilihat dari $\mathrm{R}^{2}$ adalah 0.750 atau dapat dikatakan sebesar $75 \%$. Hal ini berarti variabel indenden yaitu compliance, assurance, reliability, tangibility, empathy, dan responsiveness memiliki kontribusi sebesar $75 \%$ terhadap kepuasan nasabah bank syariah, sedangkan sisanya yaitu sebesar $25 \%$ dijelaskan oleh variabel lain diluar variabel yang digunakan, atau dapat juga dikatakan terdapat pengaruh lain seperti faktor promosi, loyalitas, nilai produk, dan lainlain.

Hasil uji pendugaan variabel bebas terhadap variabel terikat sebagaimana dapat dilihat dari tabel dibawah ini:

Tabel 1

Ringkasan hasil perhitungan uji parsial (uji t) bank syariah

\begin{tabular}{|l|l|r|r|}
\hline \multicolumn{3}{|c|}{ Coefficients $^{\text {a }}$} \\
\hline \multicolumn{1}{|c|}{} & \multicolumn{1}{c|}{$\mathrm{t}$} & \multicolumn{1}{c|}{ Sig. } \\
\hline 1 & & .003 & .998 \\
& (Codel & 2.163 & .033 \\
& compliance & 1.968 & .052 \\
& assurance & 2.212 & .030 \\
& reliability & 2.009 & .048 \\
& tangibility & 2.358 & .021 \\
& empathy & 2.101 & .039 \\
\hline
\end{tabular}

Sumber: data diolah, 2015

Dari hasil uji regresi pada tabel 1 bahwa hasil perhitungan variabel (X1) nilai yang dihasilkan sebesar 2.163 yaitu dari kriteria pengujian nilai tersebut adalah nilai $\mathrm{t}$-hitung. Untuk menarik kesimpulan nilai tersebut dibandingkan dengan nilai ttabel sebesar 1,987. Dari hasil perhitungan ternyata $\mathrm{t}_{\text {-hitung }}>\mathrm{t}$-tabel yaitu 2,163 $>1,987$ artinya $\mathrm{H}_{0}$ ditolak. Sehingga hipotesis yang berbunyi terdapat pengaruh yang signifikan antara compliance terhadap kepuasan nasabah bank syariah dengan koefisien regresi $\beta=0$ adalah diterima. Berdasarkan pengujian terhadap nilai probalitas atau nilai sig dapat diketahui dari hasil nilai sig pada tabel diatas yaitu nilai yang dihasilkan adalah sebesar 0.033 , dimana nilai tersebut tidak melebihi dari nilai $\alpha$, yaitu $0.033<5 \%$, maka kesimpulannya $\mathrm{H}_{0}$ ditolak.

Jadi dari pengujian diatas dapat disimpulkan bahwa secara parsial terdapat pengaruh signifikan antara variabel compliance (kepatuhan) yang mencakup tata kelola prinsip syariah, layanan islami, tidak adanya unsur riba dan prinsip bagi hasil (X1) terhadap kepuasan nasabah bank syariah di Surakarta. Adanya pengaruh compliance (kepatuhan) terhadap kepuasan nasabah bank syariah menunjukkan bahwa selama ini bank syariah di Surakarta dalam menerapkan sistem kepatuhan terhadap nilai-nilai Islam, dalam persepsi nasabah sudah merasakan bahwa nilai-nilai tersebut telah diberikan oleh bank syariah. Dari hasil penelitian ini juga memperkuat dari hasil penelitian yang telah dilakukan oleh Duriany dan Uswatun yang menyatakan bahwa variabel compliance memiliki pengaruh yang signifikan terhadap kepuasan nasabah bank syariah.

Hasil perhitungan variabel (X2) nilai yang dihasilkan sebesar 1.968 yaitu dari kriteria pengujian nilai tersebut adalah

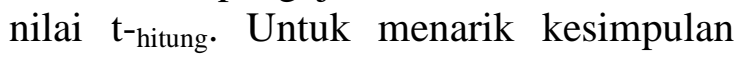
nilai tersebut dibandingkan dengan nilai ttabel sebesar 1,968. Dari hasil perhitungan ternyata $\mathrm{t}_{\text {-hitung }}<\mathrm{t}$-tabel yaitu $1.968<1,987$ artinya $\mathrm{H}_{0}$ diterima. Sehingga hipotesis yang berbunyi terdapat pengaruh yang signifikan antara assurance terhadap kepuasan nasabah bank syariah dengan koefisien regresi $\beta=0$, adalah ditolak. Berdasarkan pengujian terhadap nilai probalitas atau nilai sig dapat diketahui dari hasil nilai sig pada tabel diatas yaitu nilai yang dihasilkan adalah sebesar 0.052 , dimana nilai tersebut melebihi dari nilai $\alpha$, 
yaitu $0.052>5 \%$, maka kesimpulannya $\mathrm{H}_{0}$ diterima.

Jadi dari pengujian tersebut dapat disimpulkan bahwa secara parsial tidak terdapat pengaruh antara variabel assurance (jaminan dan kepastian) yang mencakup karyawan profesional, ramah, ketenangan hati dan mudah diakses (X2) terhadap kepuasan nasabah bank syariah di Surakarta. Tidak adanya pengaruh assurance (jaminan dan kepastian) terhadap kepuasan nasabah bank syariah menunjukkan bahwa jaminan dan keamanan yang diberikan bank syariah di Surakarta telah belum dirasakan yang terbaik kepada nasabah yaitu dengan bersikap ramah, profesional, dapat dipercaya, dan mudah diakses. Dari hasil penelitian ini juga memperkuat dari hasil penelitian yang telah dilakukan oleh Astuti yang menyatakan bahwa variabel assurance memiliki tidak berpengaruh secara signifikan terhadap kepuasan nasabah bank syariah.

Hasil perhitungan variabel (X3) nilai yang dihasilkan sebesar 2.212 yaitu dari kriteria pengujian nilai tersebut adalah nilai t-hitung. Untuk menarik kesimpulan nilai tersebut dibandingkan dengan nilai ttabel sebesar 1,987. Dari hasil perhitungan ternyata $\mathrm{t}_{\text {-hitung }}>\mathrm{t} \mathrm{t}_{\text {tabel }}$ yaitu $2.212>1,987$ artinya $\mathrm{H}_{0}$ ditolak. Sehingga hipotesis yang berbunyi terdapat pengaruh yang signifikan antara reliability terhadap kepuasan nasabah bank syariah dengan koefisien regresi $\beta=0$, adalah diterima. Berdasarkan pengujian terhadap nilai probalitas atau nilai sig dapat diketahui dari hasil nilai sig pada tabel diatas yaitu nilai yang dihasilkan adalah sebesar 0.030 , dimana nilai tersebut tidak melebihi dari nilai $\alpha$, yaitu $0.030<5 \%$, maka kesimpulannya adalah $\mathrm{H}_{0}$ ditolak.

Jadi dari pengujian tersebut dapat disimpulkan bahwa secara parsial terdapat pengaruh antara variabel reliability (kehandalan) yang mencakup kemudahan, kecepatan, ketepatan dan keamanan (X3) terhadap kepuasan nasabah bank syariah di Surakarta. Adanya pengaruh reliability (kehandalan) terhadap kepuasan nasabah bank syariah menunjukkan bahwa pelayanan yang diberikan bank syariah di Surakarta selama ini telah dirasakan hal yang terbaik dari nasabah yaitu dengan membantu memecahkan masalah, tepat waktu, pelayanan sesuai yang dijanjikan dan menyimpan data-data secara akurat. Dari hasil penelitian ini juga memperkuat dari hasil penelitian yang telah dilakukan oleh Duriany dan uswatun yang menyatakan bahwa variabel reliability memiliki pengaruh yang signifikan terhadap kepuasan nasabah bank syariah.

Hasil perhitungan variabel (X4) nilai yang dihasilkan sebesar 2.009 yaitu dari kriteria pengujian nilai tersebut adalah

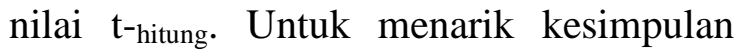
nilai tersebut dibandingkan dengan nilai ttabel sebesar 1,987. Dari hasil perhitungan ternyata $\mathrm{t}_{\text {-hitung }}>\mathrm{t}$-tabel yaitu $2.009>1,987$ artinya $\mathrm{H}_{0}$ ditolak. Sehingga hipotesis yang berbunyi terdapat pengaruh yang signifikan antara tangibility terhadap kepuasan nasabah bank syariah dengan koefisien regresi $\beta=0$, adalah diterima. Berdasarkan pengujian terhadap nilai probalitas atau nilai sig juga dapat diketahui bahwa dari hasil nilai sig pada tabel diatas yaitu nilai yang dihasilkan adalah sebesar 0.048 , dimana nilai tersebut kurang dari nilai $\alpha$ yang sebesar $<5 \%$, maka kesimpulannya $\mathrm{H}_{0}$ ditolak.

Jadi dari pengujian tersebut dapat disimpulkan bahwa secara parsial terdapat pengaruh antara variabel tangibility (bukti fisik) yang mencakup penampilan, perlengkapan, dan fasilitas (X4) terhadap kepuasan nasabah bank syariah di Surakarta. Adanya pengaruh tangibility (bukti fisik) terhadap kepuasan nasabah bank syariah menunjukkan bahwa pelayanan yang diberikan bank syariah di Surakarta telah dirasakan hal yang terbaik 
kepada nasabah yaitu dengan penampilan menarik/rapi, perlengkapan modern, dan fasilitas yang sesuai. Dari hasil penelitian ini juga memperkuat dari hasil penelitian yang telah dilakukan oleh Astuti yang menyatakan bahwa variabel tangibility memiliki pengaruh yang signifikan terhadap kepuasan nasabah bank syariah.

Hasil perhitungan variabel (X5) nilai yang dihasilkan sebesar 2.358 yaitu dari kriteria pengujian, nilai tersebut adalah nilai $\mathrm{t}_{\text {-hitung. Untuk menarik }}$ kesimpulan nilai tersebut dibandingkan dengan nilai $t_{- \text {tabel }}$ sebesar 1,987. Dari hasil perhitungan ternyata $\mathrm{t}_{\text {-hitung }}>\mathrm{t}^{\mathrm{t}}$ tabel yaitu $2.358>1,987$ artinya $\mathrm{H}_{0}$ ditolak. Sehingga hipotesis yang berbunyi terdapat pengaruh yang signifikan antara empathy terhadap kepuasan nasabah bank syariah dengan koefisien regresi $\beta=0$, adalah diterima. Berdasarkan pengujian terhadap nilai probalitas atau nilai sig dapat diketahui dari hasil nilai sig pada tabel diatas yaitu nilai yang dihasilkan adalah sebesar 0.021, dimana nilai tersebut kurang dari nilai $\alpha$ yang sebesar $<5 \%$, maka kesimpulannya $\mathrm{H}_{0}$ ditolak.

Jadi dari pengujian tersebut dapat disimpulkan bahwa secara parsial terdapat pengaruh antara variabel empathy (perhatian tulus) yang mencakup perhatian, kebutuhan spesifik, produk yang menguntungkan, biaya, jam kerja yang tepat dan lokasi yang strategis (X5) terhadap kepuasan nasabah bank syariah di Surakarta. Adanya pengaruh empathy (perhatian tulus) terhadap kepuasan nasabah bank syariah menunjukkan bahwa perhatian tulus yang diberikan layanan bank syariah di Surakarta tidak membuat ragu untuk menjalin kerja sama dengan bank syariah dalam berbagai berbagai transaksi. Dari hasil penelitian ini juga memperkuat dari hasil penelitian yang telah dilakukan oleh Duriany dan uswatun yang menyatakan bahwa variabel empathy memiliki pengaruh yang signifikan terhadap kepuasan nasabah bank syariah.

Hasil perhitungan variabel (X6) nilai yang dihasilkan sebesar 2.101 yaitu dari kriteria pengujian, nilai tersebut

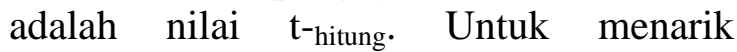
kesimpulan nilai tersebut dibandingkan dengan nilai t-tabel sebesar 1,987. Dari hasil perhitungan ternyata $\mathrm{t}_{\text {-hitung }}>\mathrm{t}_{\text {-tabel }}$ yaitu $2.101>1,987$ artinya $\mathrm{H}_{0}$ ditotak. Sehingga hipotesis yang berbunyi terdapat pengaruh yang signifikan antara responsiveness terhadap kepuasan nasabah bank syariah dengan koefisien regresi $\beta=0$, adalah diterima. Berdasarkan pengujian terhadap nilai probalitas atau nilai sig dapat diketahui dari hasil nilai sig pada tabel diatas yaitu nilai yang dihasilkan adalah sebesar 0.039, dimana nilai tersebut kurang dari nilai $\alpha$, yaitu $0.039<5 \%$, maka kesimpulannya $\mathrm{H}_{0}$ ditolak.

Jadi dari pengujian tersebut dapat disimpulkan bahwa secara parsial terdapat pengaruh antara variabel responsiveness (ketanggapan) yang mencakup kemauan membantu nasabah, kejelasan informasi, dan pengaduan atau keluhan (X6) terhadap kepuasan nasabah bank syariah di Surakarta. Adanya pengaruh responsiveness (ketanggapan) terhadap kepuasan nasabah bank syariah menunjukkan bahwa pihak bank syariah di Surakarta telah dirasakan hal yang terbaik kepada nasabah yaitu dengan ketersediaan membantu nasabah, kejelasan informasi, dan kesigapan dalam menaggapi permintaan dan keluhan nasabah dapat dirasakan oleh nasabah. Dari hasil penelitian ini juga memperkuat dari hasil penelitian yang telah dilakukan oleh Duriany dan uswatun yang menyatakan bahwa variabel responsiveness memiliki pengaruh yang signifikan terhadap kepuasan nasabah bank syariah.

Sedangakan hasil dari uji $F$ dilakukan dapat diketahui dari hasil yang diperoleh pada kolom $\mathrm{F}$ dan juga dari hasil 
kolom sig. Untuk mengetahui hasil dari pengaruh dari setiap variabel independen secara simultan yaitu variabel compliance, assurance, reliability, tangibility, empathy, dan responsiveness terhadap variabel dependen yaitu kepuasan nasabah bank syariah diperoleh nilia $\mathrm{F}_{\text {-hitung }}$ sebesar 41.586, dengan df1: 7-1 = 6 dan df2: 90-7 $=83$, maka dapat diketahui $\mathrm{F}_{\text {tabel }}$ sebesar 2,209. Untuk menarik kesimpulan nilai Fhitung tersebut dibandingkan dengan nilai Ftabel, dari hasil perhitungan ternyata $\mathrm{F}_{\text {-hitung }}$ $>\mathrm{F}_{\text {-tabel }}$ yaitu $41.586>2.209$ artinya $\mathrm{H}_{0}$ ditolak. Dilain pihak berdasarkan pengujian terhadap nilai probalitas atau nilai sig dapat diketahui dari hasil nilai sig pada tabel diatas yaitu nilai yang dihasilkan adalah sebesar 0.000, dimana nilai tersebut kurang dari nilai $\alpha$ yang sebesar $<5 \%$, maka kesimpulannya $\mathrm{H}_{0}$ ditolak dan menerima Ha.

Jadi dari pengujian tersebut, dapat disimpulkan bahwa hipotesis yang berbunyi terdapat pengaruh yang signifikan variabel compliance, assurance, reliability, tangibility, empathy, dan responsiveness $(\mathrm{X} 1, \mathrm{X} 2, \mathrm{X} 3, \mathrm{X} 4, \mathrm{X} 4, \mathrm{X} 5$, dan X6) terhadap variabel dependen yaitu kepuasan nasabah bank syariah (Y) dengan koefisien regresi $\beta_{1} \neq 0 \beta_{2} \neq 0$, adalah benar. Adanya pengaruh tersebut menunjukkan bahwa kualitas pelayanan yang diberikan bank syariah di Surakarta selama ini sesuai dengan harapan nasabah. Dari hasil penelitian ini juga memperkuat dari hasil penelitian yang telah dilakukan oleh Duriany dan uswatun yang menyatakan bahwa variabel compliance, assurance, reliability, tangibility, empathy, responsiveness memiliki pengaruh yang signifikan terhadap kepuasan nasabah bank syariah.

Model regresi dihasilkan adalah untuk mengetahui persamaan regresi pada variabel compliance, asssurance, reliability, tangibility, empathy, dan responsiveness dengan kepuasan nasabah bank syariah di Surakarta, yaitu guna memprediksi (ramalan) bagaimana keadaan (naik turunnya) secara individu setiap variabel independen mempengaruhi perubahan terhadap variabel kepuasan nasabah. Dilain sisi juga untuk mengetahui variabel manakah yang paling dominan dalam meramalkan varibel independen. Adapun model regresi bank syariah pada penelitian ini sebagai berikut:

\section{Tabel 2}

Ringkasan hasil perhitungan model regresi bank syariah

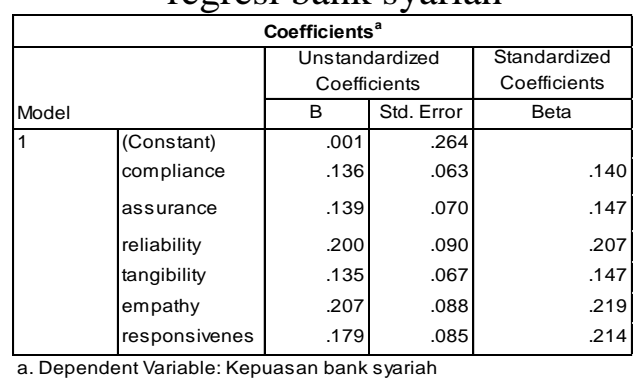

Sumber: data diolah, 2015

Berdasarkan tabel 2 dapat diketahui fungsi model regresi ganda bank syariah dapat dituliskan sebagai berikut:

$$
\begin{aligned}
& Y=\alpha+\beta_{1} X_{1}+\beta_{2} X_{2}+\beta_{3} X_{3}+ \\
& \beta_{4} X_{4}+\beta_{5} X_{5}+\beta_{6} X_{6} \\
& Y=0.001+0.136 X_{1}+ \\
& 0.139 X_{2}+0.200 X_{3}+0.135 X_{4} \\
& +0.207 X_{5}+ \\
& 0^{0.179 X_{6}}
\end{aligned}
$$

Koefisien regresi berganda dari persamaan tersebut adalah $\mathrm{X} 1=0.136, \mathrm{X} 2$ $=0.139, \mathrm{X} 3=0.200, \mathrm{X} 4=0,135, \mathrm{X} 5=$ 0.207 dan $X 6=0.179$. Hal ini berarti jika setiap variabel independen meningkat satusatuan, maka variabel compliance (X1) pengaruhnya terhadap variabel kepuasan nasabah akan bertambah sebesar 13,6\%, assurance (X2) pengaruhnya terhadap variabel kepuasan nasabah akan bertambah sebesar 13,9\%, reliability (X3) pengaruhnya terhadap variabel kepuasan nasabah akan bertambah sebesar 20\%, tangibility (X4) pengaruhnya terhadap 
variabel kepuasan nasabah akan bertambah sebesar 13,5\%, empathy (X5) pengaruhnya terhadap variabel kepuasan nasabah akan bertambah sebesar 20,7\%, dan responsiveness (X6) pengaruhnya terhadap variabel kepuasan nasabah akan bertambah sebesar $17,9 \%$.

Jadi dari hasil tersebut dapat disimpulkan bahwa variabel empathy yang paling besar pengaruhnya terhadap kepuasan nasabah bank syariah yaitu berupa perhatian tulus, tanggung jawab terhadap keamanan, produk yang menguntungkan, biaya yang rendah, operasi jam, dan lokasi yang strategis. Kemudian dilanjutkan dengan variabel reliability, dan yang paling rendah adalah variabel compliance yaitu pengelolaan sesuai hukum Islam, produk dan layanan yang Islami, tidak ada unsur riba, penerapan sistem bagi hasil. Maka dari itu pihak bank sebaiknya meningkatkan pelayanan compliance karena pengaruhnya terhadap kepuasan nasabah paling kecil dibandingkan dengan variabel yang lain.

\section{KESIMPULAN}

Berdasarkan pegolahan data dari hasil penelitian yang telah dilakukan maka dapat dikemukakan kesimpulan adalah sebagai berikut:

1. Terdapat pengaruh positif dan signifikan dari kinerja kualitas jasa bank umum syariah di Surakarta, dimana hasil dari dimensi compliance, reliability, tangibility, empathy, responsiveness secara individu terhadap kepuasan nasabah bank umum syariah. Sedangkan untuk varibel assurance tidak terdapat pengaruh yang signifikan.

2. Model CARTER ini cukup baik untuk memprediksi kepuasan nasabah, hal itu dikarenakan terdapat pengaruh yang signifikan dari dimensi-dimensi CARTER secara bersama-sama terhadap kepuasan nasabah bank umum syariah di Surakarta dan lulus dalam pengujian asumsi klasik.

3. Pengaruh positif dan terbesar terhadap kepuasan nasabah bank umum syariah di Surakarta adalah dimensi empathy, reliabity, compliance, responsiveness, tangible dan yang terakhir adalah assurance. Ini menandakan bahwa yang berpengaruh dominan terhadap kepuasan nasabah adalah empathy yaitu perhatian tulus yang diberikan oleh pihak bank kepada nasabah. Sedangkan kualitas yang masih kurang dirasakan oleh nasabah adalah pada dimensi assurance yaitu jaminan dan kepastian terhadap kepuasan nasabah bank syariah, dimana menunjukkan jaminan dan keamanan yang diberikan telah belum dirasakan yang terbaik oleh nasabah yaitu dengan bersikap ramah, profesional, dapat dipercaya, dan mudah diakses.

\section{DAFTAR PUSTAKA}

Abdulqawi Othman dan Lynn Owen, "Adopting and Measuring Customer Service Quality (SQ) in Islamic Banks; a Case Study in Kuwait Finance House", International Journal of Islamic Financial Services, Volume 3, No. 1, April-June 2001, http://islamic-finance.net/journals/ journal9/abdulqawi.pdf

Astuti, Septin Puji, et, al.,, 2009, "Meningkatkan Kualitas Pelayanan di Bank Syariah; Penelitian dengan Fuzzy Servqual dan Dimensi Carter", Jurnal Manajemen Bisnis Vol. 2 No. 1 April-Juli 2009 (47-58). 
Dharmayanti, Diah. 2006. "Analisis Dampak Service Performance Dan Kepuasan Sebagai Moderating Variable Terhadap Loyalitas Nasabah". Jurnal Manajemen Pemasaran, Vol. 1, No. 1, April 2006: $35-43$

Hasan, Ali. 2010. "Marketing Bank Syariah Cara Jitu Meningkatkan Pertumbuhan Pasar Bank Syariah". Ghalia Indonesia. Bogor.

Hasan, M. Iqbal. 2002, "Pokok-Pokok Materi Metodologi Penelitian dan Aplikasinya", Cetakan Pertama, Ghalia Indonesia, Jakarta.

Hasanah, Uswatun, 2013, “Analisis Pengaruh Kualitas Pelayanan Pt. Bank Muamalat Indonesia Cabang palu Terhadap Tingkat Kepuasan Nasabah", ISTIQRA', Jurnal Penelitian Ilmiah, Vol. 1, No. 1 Januari-Juni 2013

http://economy.okezone.com/read/2013/03 /07/457/772547/januari-2013-asetbank-umum-di-surakarta-tumbuh-2261 (diakses tanggal 2 januari 2015)

http://rri.co.id/post/berita/106698/ekonomi/ lambat_pertumbuhan_perbankan_sya riah_di_surakarta.html (diakses tanggal 2 januari 2015)

Kotler, Philip, 1994, Manajemen Pemasaran : Analisis, Perencanaan, Implementasi dan Pe-ngendalian, Salemba Empat, Jakarta

Sangadji, Etta Mamang dan Sopiah. 2013. "Perilaku konsumen". CV. Andi Offset. Yogyakarta.

Tjiptono, Fandy 2000. "Prinsip-prinsip Total Quaiity Service". CV. Andi Offset.Yogyakarta.

Wijaya, Tony. 2011. "Manajemen Kualitas Jasa”. Indeks. Jakarta. 